\title{
Advances in autism research, 2021: continuing to decipher the secrets of autism
}

\author{
Julio Licinio $\mathbb{1}^{1} \cdot$ Ma-Li Wong ${ }^{1}$
}

Received: 7 May 2021 / Accepted: 10 May 2021

(c) The Author(s), under exclusive licence to Springer Nature Limited 2021

We are proud to publish this Special Issue focused on autism, a topic that has been exceedingly important for Molecular Psychiatry since our inception. It is not too bold a statement to say that we were a fundamental contributor to bringing autism to the forefront of the national discourse. A Pubmed search reveals 403 articles published in Molecular Psychiatry since our founding in 1996. Our first autism article by Vincent et al., published in July 1996, examined the fragile $\mathrm{X}$ syndrome gene (FMR1) for mutations in autistic individuals, using single-stranded conformational polymorphism analysis; those authors identified three new FMR1 polymorphisms and identified specific and significant association findings with autism [1].

In late 2001-early 2002 we received four exciting papers with findings on the genetics of autism that were published together in our March 2002 issue, with an accompanying editorial [2-6]. We issued then a press release that was picked up by Time magazine and served as the basis for their unprecedented May 6, 2002 cover story on autism, featuring as that iconic magazine's cover a young boy who was visibly autistic [7]. That was the first time that a person with autism was the cover of a national magazine. The magazine's cover displayed in big yellow letters "Inside the world of autism" and it had a subtitle stating "More than one million Americans may have it, and the number of new cases is exploding. What scientists have discovered. What families should know." The full story, by Nash [8], was entitled: "The Secrets of Autism," with the following subtitle: "The number of children diagnosed with autism and Asperger's in the U.S. is exploding. Why?" Time's cover article was so successful that their editors expanded that from a single issue into an entire series on autism over

Julio Licinio

juliolicinio@gmail.com

1 State University of New York, Upstate Medical University, Syracuse, NY, USA multiple issues. That Time series effectively made autism emerge as a mainstream topic of kitchen table conversations across America. As that effort was triggered by our press release and four articles on autism, it is reasonable to boast that Molecular Psychiatry launched the national conversation on autism.

The four papers highlighted in our March 2002 issue were within the first 20 articles that we published on this topic. Now, 383 papers later, we have a much more substantial body of work that further unravels the secrets of autism, the culmination of which is this autism Special Issue, with 26 truly superb papers on autism [9-34]. These extraordinary articles cover essentially all aspects of this disorder, from the training of specialists, to the interface with other disorders, such as polycystic ovarian syndrome and Alzheimer's disease, and in-depth analyses of genetics, structural and functional imaging, as well as neuroscience, including postmortem brain studies, transcriptome of induced pluripotent stem cell models, assessments of the role of vitamin $\mathrm{D}$, and studies highlighting the contributions of inflammatory mediators to autism.

We have had for over three decades a particular interest on the interface of immune mediators and psychiatric disorders [35]. It is very rewarding to see the interface of immune mediators and psychiatry evolve from a hypothesis, that we and others explored decades ago, into a broad and established area within psychiatric neuroscience. As we have developed a new model of analysis of the simultaneous contributions of multiple genes and environmental factors to a psychiatric phenotype [36], were also encouraged to see studies looking at the polygenic risk for autism in the context of childhood trauma, life-time self-harm, and suicidal behavior and ideation [30], as well in comparison to several other psychiatric disorders [32].

One paper in this issue, by Frye et al., is highly usual, and particularly intriguing: it investigates the role of the mitochondrion, in the influence of prenatal air pollution exposure on neurodevelopment and behavior in 96 children with autism spectrum disorder [22]. Second and third 
trimester average and maximal daily exposure to fine air particulate matter of diameter $\leq 2.5 \mu \mathrm{m}\left(\mathrm{PM}_{2.5}\right)$ was obtained from the Environmental Protection Agency's Air Quality System. Mediation analysis found that mitochondrial respiration linked to energy production accounted for $25 \%$ and $10 \%$ of the effect of average prenatal $\mathrm{PM}_{2.5}$ exposure on neurodevelopment and behavioral symptoms, respectively. Those results suggest that prenatal exposure to $\mathrm{PM}_{2.5}$ disrupts neurodevelopment and behavior through complex mechanisms, including long-term changes in mitochondrial respiration and that patterns of early development need to be considered when studying the influence of environmental agents on neurodevelopmental outcomes.

We are honored to have initiated the national conversation on autism twenty years ago and we believe that the 403 autism papers published to date in Molecular Psychiatry, including, but not limited to those highlighted in this Special Issue, report major advances in a key area of molecular psychiatry. It is particularly rewarding to see that these articles cover the full spectrum of research translation [37], from molecules to society.

In future issues, Molecular Psychiatry will continue to publish outstanding advances in autism research.

\section{References}

1. Vincent JB, Konecki DS, Munstermann E, Bolton P, Poustka A, Poustka F, et al. Point mutation analysis of the FMR-1 gene in autism. Mol Psychiatry. 1996;1:227-31.

2. Licinio J, Alvarado II. Progress in the genetics of autism. Mol Psychiatry. 2002;7:229.

3. Jamain S, Betancur C, Quach H, Philippe A, Fellous M, Giros B, et al. Linkage and association of the glutamate receptor 6 gene with autism. Mol Psychiatry. 2002;7:302-10.

4. Kim SJ, Cox N, Courchesne R, Lord C, Corsello C, Akshoomoff $\mathrm{N}$, et al. Transmission disequilibrium mapping at the serotonin transporter gene (SLC6A4) region in autistic disorder. Mol Psychiatry. 2002;7:278-88.

5. Bonora E, Bacchelli E, Levy ER, Blasi F, Marlow A, Monaco AP, et al. Mutation screening and imprinting analysis of four candidate genes for autism in the $7 \mathrm{q} 32$ region. Mol Psychiatry. 2002;7:289-301.

6. Buxbaum JD, Silverman JM, Smith CJ, Greenberg DA, Kilifarski $\mathrm{M}$, Reichert J, et al. Association between a GABRB3 polymorphism and autism. Mol Psychiatry. 2002;7:311-6.

7. Time Magazine. Inside the world of autism. More than one million Americans may have it, and the number of new cases is exploding. What scientists have discovered. What families should know. Time. 2002. http://content.time.com/time/covers/0,16641, 20020506,00.html.

8. Nash M. The Secrets of Autism: The number of children diagnosed with autism and Asperger's in the U.S. is exploding. Why?" Time. 2002. http://content.time.com/time/subscriber/article/0, 33009,1002364,00.html.

9. Pasca SP, Veenstra-VanderWeele J, McPartland JC. Research and training in autism spectrum disorder to catalyze the next genomic and neuroscience revolutions. Mol Psychiatry. 2020. https://doi. org/10.1038/s41380-020-0830-5. [Epub ahead of print].
10. Lombardo MV. Ribosomal protein genes in post-mortem cortical tissue and iPSC-derived neural progenitor cells are commonly upregulated in expression in autism. Mol Psychiatry. 2020. https:// doi.org/10.1038/s41380-020-0773-x. [Epub ahead of print].

11. Griesi-Oliveira K, Passos-Bueno MR. Reply to Lombardo, 2020: An additional route of investigation: what are the mechanisms controlling ribosomal protein genes dysregulation in autistic neuronal cells? Mol Psychiatry. 2020. https://doi.org/10.1038/ s41380-020-0792-7. [Epub ahead of print].

12. Menon V, Andrade C, Thennarasu K. Polycystic ovarian syndrome and autism spectrum disorder in the offspring: Should the primary outcome have been different? Mol Psychiatry. 2019. https://doi. org/10.1038/s41380-019-0571-5. [Epub ahead of print].

13. Chapman R, Veit W. The essence of autism: fact or artefact? Mol Psychiatry 2020. https://doi.org/10.1038/s41380-020-00959-1. [Epub ahead of print].

14. Niesler B, Rappold GA. Emerging evidence for gene mutations driving both brain and gut dysfunction in autism spectrum disorder. Mol Psychiatry. 2020. https://doi.org/10.1038/s41380-0200778-5. [Epub ahead of print].

15. Antunes C, Da Silva JD, Guerra-Gomes S, Alves ND, Ferreira F, Loureiro-Campos E, et al. Tet3 ablation in adult brain neurons increases anxiety-like behavior and regulates cognitive function in mice. Mol Psychiatry. 2020. https://doi.org/10.1038/s41380-0200695-7. [Epub ahead of print].

16. Xiong GJ, Cheng XT, Sun T, Xie Y, Huang N, Li S, et al. Defects in syntabulin-mediated synaptic cargo transport associate with autism-like synaptic dysfunction and social behavioral traits. Mol Psychiatry. 2020. https://doi.org/10.1038/s41380-020-0713-9.

17. Rapanelli M, Tan T, Wang W, Wang X, Wang ZJ, Zhong P, et al. Behavioral, circuitry, and molecular aberrations by region-specific deficiency of the high-risk autism gene Cul3. Mol Psychiatry. 2019. https://doi.org/10.1038/s41380-019-0498-x. [Epub ahead of print].

18. Guo D, Peng Y, Wang L, Sun X, Wang X, Liang C, et al. Autismlike social deficit generated by Dock4 deficiency is rescued by restoration of Rac1 activity and NMDA receptor function. Mol Psychiatry. 2019. https://doi.org/10.1038/s41380-019-0472-7. [Epub ahead of print].

19. Gordon A, Forsingdal A, Klewe IV, Nielsen J, Didriksen M, Werge $\mathrm{T}$, et al. Transcriptomic networks implicate neuronal energetic abnormalities in three mouse models harboring autism and schizophrenia-associated mutations. Mol Psychiatry. 2019. https://doi.org/10.1038/s41380-019-0576-0. [Epub ahead of print].

20. Ben-Reuven L, Reiner O. Dynamics of cortical progenitors and production of subcerebral neurons are altered in embryos of a maternal inflammation model for autism. Mol Psychiatry. 2019 Nov 18. https://doi.org/10.1038/s41380-019-0594-y. [Epub ahead of print].

21. Ramirez-Celis A, Becker M, Nuno M, Schauer J, Aghaeepour N, Van de Water J. Risk assessment analysis for maternal autoantibody-related autism (MAR-ASD): a subtype of autism. Mol Psychiatry. 2021. https://doi.org/10.1038/s41380-020-009988. [Epub ahead of print].

22. Frye RE, Cakir J, Rose S, Delhey L, Bennuri SC, Tippett M, et al. Prenatal air pollution influences neurodevelopment and behavior in autism spectrum disorder by modulating mitochondrial physiology. Mol Psychiatry. 2020. https://doi.org/10.1038/s41380020-00885-2. [Epub ahead of print].

23. Lee BK, Eyles DW, Magnusson C, Newschaffer CJ, McGrath JJ, Kvaskoff D, et al. Developmental vitamin D and autism spectrum disorders: findings from the Stockholm Youth Cohort. Mol Psychiatry. 2019. https://doi.org/10.1038/s41380-019-0578-y.

24. Griesi-Oliveira K, Fogo MS, Pinto BGG, Alves AY, Suzuki AM, Morales AG, et al. Transcriptome of iPSC-derived neuronal cells 
reveals a module of co-expressed genes consistently associated with autism spectrum disorder. Mol Psychiatry. 2020. https://doi. org/10.1038/s41380-020-0669-9. [Epub ahead of print].

25. Rontani P, Perche O, Greetham L, Jullien N, Gepner B, Feron F, et al. Impaired expression of the COSMOC/MOCOS gene unit in ASD patient stem cells. Mol Psychiatry. 2020. https://doi.org/10. 1038/s41380-020-0728-2. [Epub ahead of print].

26. Ivashko-Pachima Y, Hadar A, Grigg I, Korenkova V, Kapitansky O, Karmon G, et al. Discovery of autism/intellectual disability somatic mutations in Alzheimer's brains: mutated ADNP cytoskeletal impairments and repair as a case study. Mol Psychiatry. 2019. https://doi.org/10.1038/s41380-019-0563-5. [Epub ahead of print].

27. Fung LK, Flores RE, Gu M, Sun KL, James D, Schuck RK, et al. Thalamic and prefrontal GABA concentrations but not GABAA receptor densities are altered in high-functioning adults with autism spectrum disorder. Mol Psychiatry. 2020. https://doi.org/10. 1038/s41380-020-0756-y.

28. Andersson M, Tangen A, Farde L, Bolte S, Halldin C, Borg J, et al. Serotonin transporter availability in adults with autism-a positron emission tomography study. Mol Psychiatry. 2020. https://doi.org/10.1038/s41380-020-00868-3. [Epub ahead of print].

29. Zurcher NR, Loggia ML, Mullett JE, Tseng C, Bhanot A, Richey $\mathrm{L}$, et al. [(11)C]PBR28 MR-PET imaging reveals lower regional brain expression of translocator protein (TSPO) in young adult males with autism spectrum disorder. Mol Psychiatry. 2020. https://doi.org/10.1038/s41380-020-0682-z. [Epub ahead of print].

30. Warrier V, Baron-Cohen S. Childhood trauma, life-time self-harm, and suicidal behaviour and ideation are associated with polygenic scores for autism. Mol Psychiatry.
2019. https://doi.org/10.1038/s41380-019-0550-x. [Epub ahead of print].

31. Chiang AH, Chang J, Wang J, Vitkup D. Exons as units of phenotypic impact for truncating mutations in autism. Mol Psychiatry. 2020. https://doi.org/10.1038/s41380-020-00876-3. [Epub ahead of print].

32. Ratanatharathorn A, Koenen KC, Chibnik LB, Weisskopf MG, Rich-Edwards JW, Roberts AL. Polygenic risk for autism, attention-deficit hyperactivity disorder, schizophrenia, major depressive disorder, and neuroticism is associated with the experience of childhood abuse. Mol Psychiatry. 2021. https://doi. org/10.1038/s41380-020-00996-w. [Epub ahead of print].

33. Brownstein CA, Smith RS, Rodan LH, Gorman MP, Hojlo MA, Garvey EA, et al. RCL1 copy number variants are associated with a range of neuropsychiatric phenotypes. Mol Psychiatry. 2021. https://doi.org/10.1038/s41380-021-01035-y. [Epub ahead of print].

34. Sarn N, Jaini R, Thacker S, Lee H, Dutta R, Eng C. Cytoplasmicpredominant Pten increases microglial activation and synaptic pruning in a murine model with autism-like phenotype. Mol Psychiatry. 2020. https://doi.org/10.1038/s41380-020-0681-0. [Epub ahead of print].

35. Sternberg EM, Licinio J. Overview of neuroimmune stress interactions. Implications for susceptibility to inflammatory disease. Ann N. Y Acad Sci. 1995;771:364-71.

36. Wong ML, Dong C, Andreev V, Arcos-Burgos M, Licinio J. Prediction of susceptibility to major depression by a model of interactions of multiple functional genetic variants and environmental factors. Mol Psychiatry. 2012;17:624-33.

37. Bornstein SR, Licinio J. Improving the efficacy of translational medicine by optimally integrating health care, academia and industry. Nat Med. 2011;17:1567-9. 